\title{
PENGISIAN PERANGKAT DESA BERDASARKAN PERATURAN DAERAH KABUPATEN DEMAK NOMOR 1 TAHUN 2018 TENTANG PENGANGKATAN DAN PEMBERHENTIAN PERANGKAT DESA TAHUN 2018 SUATU KAJIAN PERKARA NO.54/G/2018/PTUN.SMG
}

\author{
AMIR DARMANTO, S.H \\ Magister Hukum Universitas Semarang
}

\begin{abstract}
ABSTRAK
Penelitian ini bertujuan untuk memahami dan menganalisis proses pengisian perangkat desa Kabupaten Demak berdasarkan perda No 1 Tahun 2018 tentang pengangkatan dan pemberhentian perangkat desa dan menganalisis ketentuan yang ideal atas pengisian perangkat desa dalam kajian perkara NO.54/G/2018/PTUN.SMG
\end{abstract}

Metode yang dipergunakan dalam penulisan Penelitian ini menggunakan pendekatan penelitian yuridis empiris yang dengan kata lain adalah jenis penelitian hukum sosiologis oleh karena sasaran penelitian ini adalah hukum atau kaedah (norm) terhadap menganalisis proses pengisian perangkat desa Kabupaten Demak berdasarkan perda No 1 Tahun 2018 dan kajian perkara NO.54/G/2018/PTUN.SMG

Berdasarkan hasil penelitian dan analisis yang telah dilakukan dapat disimpulkan proses pengisian perangkat desa Kabupaten Demak dilakukan melalui 3 (tiga) tahap, tahap Pertama penjaringan yang meliputi (pengumuman, pendaftatan dan penetapan) tahap Kedua tahap Penyaringan yang meliputi (seleksi, Penilaian, dan penetapan hasil seleksi). Tahap Ketiga tahap pengangkatan. Adanya gugatan perkara NO.54/G/2018/PTUN.SMG dikarenakan adanya pelanggaran Prosedular dan Substansi yakni pasal 19 dan Pasal 20 perda No 1 Tahun 2018, salah satu faktor adanya sengketa pilperades di Kabupaten Demak adalah kurangnya pengawasan yang dilakukan Bupati Demak terhadap proses pengisian Perangkat Desa tahun 2018.

Kata Kunci: Sengketa, Pengisian perangkat Desa, dan Pengawasan, 


\title{
FILLING VILLAGE OFFICIALS BASED ON REGIONAL REGULATION OF DEMAK NUMBER 1 OF 2018 REGARDING THE APPOINTMENT AND DISMISSAL OF VILLAGE OFFICIALS IN 2018 A CASE STUDY NO. 54/G/2018/PTUN.SMG
}

\author{
AMIR DARMANTO, S.H \\ Magister of Law Universitas Semarang
}

\begin{abstract}
This study aims to understand and analyze the process of filling the village officials/apparatus of Demak Regency based on Regional Regulation No. 1 of 2018 concerning the appointment and dismissal of village officials and analyzing ideal provisions for filling village officials in case study No. 54/G/2018/PTUN.SMG.

The method used in this study uses an empirical juridical research approach that in other words is a type of sociological legal research because the target of this research is law or norms to analyze the process of filling the village apparatus in Kabupaten Demak based on Regional Regulation No. 1 of 2018 and case study No. 54/G/2018/PTUN.SMG.

Based on the results of the research and analysis that have been carried out, it can be concluded that the process of filling the village officials/apparatus of Demak Regency was carried out through 3 (three) stages. The first stage is snaring that includes (announcement, registration and determination), the second stage is screening phase that includes (selection, assessment and outcome determination), third stage is appointment. The existence of law case No. 54/G/2018/PTUN.SMG was due to Procedure and Substance violations namely Article 19 and Article 20 of Regional Regulation No. 1 of 2018. One of the factors in the dispute over Pilperades in Kabupaten Demak was the lack of supervision by the District Head of Demak on filling village officials in 2018.
\end{abstract}

Keywords: Disputes, Filling Village Devices, and Supervision. 


\section{A. Latar Belakang}

Undang-Undang Dasar 1945 sendiri menganut dua pola pembagian kekuasaan, yaitu pembagian kekuasaan negara secara Horizontal dan secara Vertikal. Dimana menurut Philipus M. Hadjon, pembagian kekuasaan negara secara Horizontal adalah pembagian kekuasaan negara kepada organ negara yang dalam ketatanegaraan disebut Lembaga Negara, sedangkan pembagian kekuasaan negara secara Vertikal adalah pembagian kekuasaan negara antara pemerintah pusat dan pemerintah daerah ${ }^{1}$.

Sejak lahirnya UndangUndang Nomor 22 Tahun 1999 tentang Pemerintahan Daerah yang kemudian diganti dengan Undang-Undang Nomor 32 Tahun 2004 tentang Pemerintahan Daerah dan telah diubah kembali dengan UndangUndang Nomor 23 Tahun 2014 tentang Pemerintahan Daerah, telah menyebabkan perubahan yang mendasar dalam tata kelola pemerintahan di daerah, baik pemerintahan di tingkat provinsi, kabupaten atau kota di Indonesia dalam hal kewenangan pemerintahan daerah mengurus daerahnya sendiri.

1 Titik Triwulan Tutik, Konstruksi Hukum Tata Negara Indonesia Pasca-Amandemen UUD 1945, Kencana, Jakarta, 2011, Hal.241
Kewenangan pemerintah daerah untuk mengatur urusan pemerintahan sendiri sebagaimana tertuang dalam Pasal 10 ayat (2) UndangUndang Nomor 23 Tahun 2014, secara hirarki merupakan implementasi secara yuridis dari Pasal 18 ayat (2) UUD 1945 NKRI setelah amandemen kedua, yang berbunyi: "Pemerintah daerah provinsi, daerah kabupaten dan kota mengatur dan mengurus sendiri urusan pemerintahan menurut asas otonomi dan tugas pembantuan.

Tujuan otonomi daerah pada hakekatnya adalah memberikan kewenangan kepada daerah untuk mengurus rumah tangga daerahnya sendiri, dengan alasan bahwa Pemerintah Daerah yang lebih mengetahui keadaan dan kondisi di daerah. Namun demikian tidak semua kewenangan pemerintah pusat diserahkan kepada pemerintah daerah. Kewenangan pemerintah pusat yang tidak diserahkan atau dilimpahkan kepada pemerintah daerah berdasar Pasal 10 ayat (3) Undang-Undang Nomor 23 Tahun 2014 tentang Pemerintahan Daerah adalah meliputi : Politik Luar Negeri, Pertahanan, Keamanan, Yustisi, Moneter dan Fiskal Nasional dan Urusan Agama. 
Dengan adanya

kewenangan untuk mengurus daerah sendiri berdasarkan Undang Undang tentang pemerintah Daerah, mengharuskan pemerintahan di daerah membentuk regulasiregulasi dalam upaya melaksanakan roda pemerintahan di daerah yaitu dengan melahirkan peraturan daerah-peraturan daerah yang sesuai dengan kebutuhan dan kondisi daerah. Kewenangan pemerintahan daerah dalam membentuk peraturan daerah, mempunyai legitimasi atau dasar yang kuat, yakni secara yuridis formal didasari dalam UUD 1945 pada Pasal 18 ayat (6), yang berbunyi: Pemerintahan daerah berhak menetapkan Peraturan Daerah dan peraturan-peraturan lain untuk melaksanakan otonomi dan tugas pembantuan.Kemudian juga diatur di dalam Undang-Undang Nomor 23 Tahun 2014 tentang Pemerinah Daerah pada Pasal 136 ayat (1), yang berbunyi sebagai berikut: Perda ditetapkan oleh Kepala Daerah setelah mendapatkan persetujuan bersama DPRD. Pemerintahan Daerah yang dimaksud dalam Undang-Undang Dasar 1945 dalam Pasal (18) ini bukan saja Gubernur, Bupati dan Walikota, akan tetapi termasuk di dalamnya adalah Dewan
Perwakilan Rakyat Daerah (DPRD).

Peraturan daerah yang dibentuk oleh Pemerintahan Daerah baik Gubernur, Bupati, Walikota bersama dengan Dewan Perwakilan Rakyat Daerah, pada dasarnya mempunyai fungsi ${ }^{2}$ :

a. sebagai instrumen kebijakan untuk melaksanakan otonomi daerah dan tugas pembantuan sebagaimana diamanatkan dalam Undang-Undang Dasar Negara Kesatuan Republik Indonesia Tahun 1945 dan Undang-Undang tentang Pemerintahan Daerah;

b. merupakan peraturan pelaksana dari Peraturan Perundang-undangan yang lebih tinggi;

c. dalam fungsi ini, Peraturan Daerah tunduk pada ketentuan hierarki peraturan perundangundangan, dengan demikian Peraturan Daerah tidak boleh bertentangan dengan Peraturan Perundangundangan yang lebih tinggi;

${ }^{2}$ Dirjen Peraturan perundang undangan, Panduan Praktis Memahami Perancangan Peraturan Daerah, Penerbit Caplet Project 2008. hal. 7. 
d. sebagai penampung

kekhususan dan

keragaman daerah serta

penyalur aspirasi

masyarakat di daerah,

namun dalam

pengaturannya tetap

dalam koridor Negara

kesatuan Republik

Indonesia yang

berlandaskan Pancasila

dan Undang-Undang

Dasar Negara Republik Indonesia Tahun 1945; dan

e. sebagai alat

pembangunan yang

digunakan untuk

meningkatkan

kesejahteraan daerah.

Kemudian, peraturan

daerah merupakan fungsi yang bersifat atribusi maksudanya bahwa Peraturan daerah melekat kewenangan-kewenangan

sebagaimana diatur berdasarkan Undang-Undang Nomor 23 Tahun 2014 tentang Pemerintahan Daerah, terutama dalam Pasal 136 yaitu:

a. Menyelenggarakan pengaturan dalam rangka penyelenggaraan otonomi daerah dan tugas pembantuan.

b. Menyelenggarakan pengaturan sebagai penjabaran lebih lanjut peraturan perundangundangan yang lebih tinggi dengan memperhatikan ciri khas masing- masing daerah.

c. Menyelenggarakan

pengaturan hal-hal yang tidak bertentangan dengan kepentingan umum.

d. Menyelenggarakan pengaturan hal-hal yang tidak bertentangan dengan peraturan perundangundangan yang lebih tinggi.

Peraturan daerah merupakan penyelenggaraan dari ketentuan- ketentuan atau penjabaran lebih lanjut dari peraturan yang lebih tinggi, hal ini diatur di dalam UndangUndang Nomor 32 Tahun 2004 tentang Pemerintahan Daerah dalam Pasal 136 ayat (3), yang berbunyi: Perda sebagaimana yang dimaksud pada ayat (1) merupakan penjabaran lebih lanjut dari peraturan perundangundangan yang lebih tinggi dengan memperhatikan ciri khas masing masing daerah.

Peraturan Daerah bisa juga pelaksanaan dari peraturan menteri, peraturan menteri itu lebih tinggi dari peraturan daerah, oleh karena peraturan daerah lingkup berlakunya terbatas pada daerah yang bersangkutan, sedangkan peraturan menteri ruang berlakunya mencakup seluruh wilayah Negara Republik Indonesia, maka secara 
hierarki, peraturan menteri berada di atas peraturan daerah, meskipun peraturan menteri tidak secara tegas dicantumkan dalam hierarki peraturan perundangundangan dalam Pasal 7 ayat (1) Undang-Undang Nomor 12 Tahun 2011 tentang Pembentukan Peraturan Perundang-Undangan. Akan tetapi imflisit diakui sebagai salah satu jenis peraturan perundang undangan ${ }^{3}$.

Lebih lanjut Peraturan Daerah secara yuridis ruang lingkup keberlakuannya terbatas pada daerah yang bersangkutan dalam suatu wilayah tertentu. Peraturan Daerah Provinsi dan Peraturan Daerah Kabupaten/Kota berdasarkan ketentuan Undang-Undang, maka peraturan daerah itu harus jelas dalam pengertian tidak menimbulkan multi tafsir karena merupakan penjabaran dan imflementasi dari peraturan perundang-undangan yang lebih tinggi. Peraturan Daerah seharusnya tidak lagi menimbulkan banyak penafsiran dari kaidah dan ketentuannya, karena sudah bersifat teknis, jelas dan tinggal diterapkan di lapangan.

${ }^{3}$ H.M. Aziz, Dasar Dasar Konstitusional Pemerintah Daerah Dan Pembentukan Peraturan Daerah.Makalah disampaikan pada pendidikan dan pelatihan penyusunan perancangan peraturan perundang undangan, bulan Juni tahun 2010 di Jakarta Hal 4.
Tujuan pembentukan

Peraturan Daerah sebagaimana disebutkan di atas tidak terlepas juga dari tugas pemerintah daerah untuk membina dan menciptakan kesejahteraan masyarakat daerah. Oleh karena itu Peraturan Daerah yang dibuat haruslah sesuai dengan keadaan dan kondisi masyarakat di mana peraturan daerah tersebut diberlakukan.

Sejak ditetapkannya Undang - Undang Nomor 6 Tahun 2014 tentang Desa, maka Pemerintah, Pemerintah Daerah Provinsi, dan Pemerintah Daerah Kabupaten atau Kota dapat melakukan penataan Desa. Penataan sebagaimana dimaksud dalam pasal 1 Undang - Undang Nomor 6 Tahun 2014 berdasarkan hasil evaluasi tingkat perkembangan Pemerintahan Desa sesuai dengan ketentuan Peraturan Perundang- undangan. Hal tersebut bertujuan untuk mewujudkan efektivitas penyelenggaraan Pemerintahan Desa, mempercepat peningkatan kesejahteraan masyarakat desa, mempercepat peningkatan kualitas pelayanan publik, meningkatkan kualitas tata kelola Pemerintahan Desa, dan meningkatkan daya saing Desa. ${ }^{4}$ Pemerintahan Daerah agar berjalan sesuai dengan

${ }^{4}$ Pasal 7 Ayat (3) Undang- Undang No. 6 Tahun 2014 Tentang Desa. 
asas-asas pemerintaha yang baik (AUPB) salah satunya adalah memiliki Aparatur Pemerintah yang profesional termasuk Perangkat Desa yang berkompeten agar pelayanan publik benar benar melayani. Kabupaten Demak jabatan perangkat desa pada tahun 2017 banyak mengalami kekosongan sehingga pada Bulan Januari 2017 Bupati Demak telah menerbitkan Surat Keputusan Nomor: 141/18 Tahun 2017 tentang Penetapan Desa-desa yang melaksanakan pengisian pengangkatan perangkat desa di wilayah Kabupaten Demak tahun 2017 berdasarkan Peraturan Daerah Kabupaten Demak Nomor 6 Tahun 2015 tentang Perangkat Desa (Lembaran Daerah Kabupaten Demak Tahun 2016 Nomor 6, Tambahan Lembaran Daerah Kabupaten Demak Nomor 6), akan tetapi terjadi perbedaan pendapat antara Bupati Demak dengan DPRD terkait perbedaan tafsir Perda tersebut, sehingga perda tersebut direvisi dengan mengacu kepada pertama asas filosofis, yakni perkembangan yang terjadi di masyarakat menunjukkan adanya dinamika dalam filosofi pembentukan peraturan perundang-undangan. Filosofi pemikiran yang menghendaki adanya suatu perubahan berarti adanya suatu perubahan dalam nilai-nilai yang mendasari suatu undangundang, baik yang berkaitan dengan nilai-nilai ideal, norma dasar yang menjiwai, dan materi muatan yang mengaturnya. Hal ini tidak terlepas dari adanya dinamika dalam pemikiran, gagasan atau ide-ide dari nilainilai yang hidup dan berkembang di masyarakat yang selalu menginginkan adanya kemajuan dalam berfikir dan bertindak untuk mewujudkan tujuan hidup bersama yaitu kesejahteraan umum, kemakmuran, ketertiban, perdamaian abadi dan keadilan sosial. Kedua asas Yuridis Secara yuridis, Undang-Undang adalah produk politik. UndangUndang selalu berisikan materi atau substansi yang diwarnai dengan berbagai kepentingan politik di dalamnya. Situasi politik pada saat suatu Undang-Undang disetujui tentunya akan berbeda dengan situasi sosial politik terkini, apalagi kalau masih terdapat alasan yuridis lainnya. Oleh karena itu, perubahan suatu Undang-Undang merupakan suatu keharusan yuridis karena hukum merupakan suatu hal yang dinamis. Dalam dinamika yuridis tersebut, Undang-Undang merupakan hasil persetujuan bersama antara Pemerintah dan Dewan Perwakilan Rakyat (DPR). Undang-Undang yang merupakan hasil persetujuan bersama tersebut menjadi produk hukum yang mengikat secara 
umum. Ketiga asas Secara sosiologis, dinamika dan perkembangan pesat yang terjadi di masyarakat mencerminkan adanya perubahan atau pergeseran situasi dan kondisi terkini yang terjadi di masyarakat, baik dinamika yang terjadi di sektor sosial, politik, ekonomi, budaya, pemerintahan, dan lain sebagainya. Hal ini menunjukkan adanya keinginan masyarakat untuk mengaktualisasikan dan menyesuaikan situasi dan kondisi terkini ke dalam peraturan perundang-undangan yang ada, sehingga hukum merupakan suatu hal yang selalu dinamis, dan bukan suatu hal yang statis Dari aspek sosiologis, hukum bersifat responsif terhadap perkembangan yang terjadi di masyarakat.

\begin{tabular}{lrr}
\multicolumn{2}{c}{ Terbitnya } & Peraturan \\
Daerah & Kabupaten & Demak \\
Nomor 1 & Tahun 2018 & Tentang \\
Pengangkatan & Dan
\end{tabular}

Pemberhentian Perangkat Desa perda inilah yang menjadi pijakan dalam pengisian perangkat desa di Kabupaten Demak. Meskipun perda tersebut telah direvisi dan tahapan pelaksanaan pengisian perangkat di Kabupaten Demak telah dijalankan akan tetapi proses pengisian perangkat di Kabupaten Demak tahun 2018 terindikasi terjadi Kolusi,Koropsi,dan Nepotisme sehingga banyak muncul gugatan ke Pengadilan Tata
Usaha Negara Semarang, salah satunya adalah gugatan dari peserta pengisian perangkat Desa Cabean Kecamatan Demak Kabupaten Demak terhadap Surat Keputusan Kepala Desa yang melantik peserta hasil seleleksi pengisian perangkat tersebut, Berdasarkan uraian diatas, penulis berkeinginan untuk mengangkat dan menjadikannya dalam sebuah penulisan Tesis dengan judul "Pengisian Perangkat Desa Berdasarkan Peraturan Daerah Kabupaten Demak Nomor 1 Tahun $2018 \quad$ Tentang Pengangkatan Dan Pemberhentian Perangkat Desa Tahun 2018 Suatu Kajian Perkara No.54/G/2018/Ptun.Smg"

\section{B. Perumusan Masalah}

1. Bagaimanakah proses pengisian perangkat desa Kabupaten Demak berdasarkan perda No 1 Tahun 2018 tentang pengangkatan dan pemberhentian perangkat desa?

2. Bagaimanakah ketentuan yang ideal atas pengisian perangkat desa dalam kajian perkara NO.54/G/2018/PTUN.SMG ?

\section{Metode Penelitian}

Metode yang dipergunakan dalam penulisan Penelitian ini menggunakan pendekatan penelitian yuridis empiris yang dengan kata lain adalah jenis penelitian hukum sosiologis oleh 
karena sasaran penelitian ini adalah hukum atau kaedah (norm) terhadap menganalisis proses pengisian perangkat desa Kabupaten Demak berdasarkan perda No 1 Tahun 2018 dan kajian

NO.54/G/2018/PTUN.SMG

\section{Pembahasan}

\section{Proses Pengisian Perangkat Desa Kabupaten Demak} Berdasarkan Perda No 1 Tahun 2018 Tentang Pengangkatan Dan Pemberhentian Perangkat Desa

Kabupaten Demak merupakan sebuah daerah yang berada di pesisir pulau jawa dengan mayoritas penduduknya tinggal di pedesaan, Kabupaten Demak terdiri dari 14 Kecamatan dan 235 desa $^{5}$ Pemerintahan desa merupakan bagian dari pemerintahan nasional yang penyelenggaraannya ditujukan pada pedesaan. Pemerintah Desa adalah Kepala Desa atau yang disebut dengan nama lain dibantu perangkat Desa sebagai unsur

${ }^{5}$ Lihat pasal 1 ayat 1 Undang Undang no 6 tahun 2016 " Desa adalah desa dan desa adat atau yang disebut dengan nama lain, selanjutnya disebut Desa, adalah kesatuan masyarakat hukum yang memiliki batas wilayah yang berwenang untuk mengatur dan mengurus urusan pemerintahan, kepentingan masyarakat setempat berdasarkan prakarsa masyarakat, hak asal usul, dan/atau hak tradisional yang diakui dan dihormati dalam sistem pemerintahan Negara Kesatuan Republik Indonesia." penyelenggara

Pemerintahan

Desa ${ }^{6}$.

Pemerintahan di Desa

dilakukan oleh Kepala Desa yakni sesorang yang bertugas menyelenggarakan urusan Pemerintahan di Desa, melaksanakan Pembangunan di Desa, dan pembinaan kemasyarakatan di Desa, serta melakukan pemberdayaan masyarakat desa, dalam melaksanakan tugasnya Kepala Desa dibantu oleh Perangkat Desa. Yang terdiri dari sekretariat desa, pelaksana kewilayahan, pelaksana teknis. Perangkat desa bertugas membantu kepala desa dalam melaksanakan tugas dan wewenangnya. Dengan demikian, perangkat desa bertanggungjawab kepada kepala desa. Perangkat Desa diangkat oleh Kepala Desa setelah dikonsultasikan dengan Camat atas nama Bupati atau Walikota. Dalam melaksanakan tugas dan wewenangnya

Sebagaimana diketahui bahwa untuk mengatur pelaksanaan pengangkatan dan pemberhentian Perangkat Desa, telah ditetapkan Peraturan Daerah Nomor 6 Tahun 2015 tentang Perangkat Desa. Dengan ditetapkannya Undang-Undang Nomor 6 Tahun 2014 tentang Desa yang ditindaklanjuti dengan Peraturan Pemerintah Nomor 43 Tahun 2014 tentang Pelaksanaan

${ }^{6}$ Pasal 1 ayat 3 Undang-undang No 6 tahun 2014 
Undang-Undang Nomor 6 Tahun 2014 tentang Desa dan perubahannya, Peraturan Menteri Dalam Negeri Nomor 83 Tahun 2015 tentang Pengangkatan dan Pemberhentian Perangkat Desa dan perubahannya, maka dalam rangka penyempurnaan ketentuan- ketentuan sesuai peraturan perundang-undangan yang berlaku untuk memperoleh Perangkat Desa yang kredibel, punya etos kerja tinggi dan intelektual yang memadai dengan dilakukan melalui sistem yang lebih efektif dan efisien baik dalam segi waktu maupun biaya.

\section{Ketentuan Yang Ideal Atas Pengisian Perangkat Desa Dalam Kajian Perkara NO.54/G/2018/PTUN.SMG}

Tahun 2017 Pemerintah Kabupaten Demak membuka formasi untuk pengisian perangkat desa, hal ini dikarenakan banyaknya jabatan perangkat desa yang mengalami kekosongan sehingga dapat mengangu pelayanan publik maka pada bulan Januari 2017 Bupati Demak telah menerbitkan Surat Keputusan Nomor: 141/18 Tahun 2017 tentang Penetapan Desa-desa yang melaksanakan pengisian pengangkatan perangkat desa di wilayah Kabupaten Demak tahun 2017. Dalam keputusan tersebut, Desa cabean Kecamatan Demak kota Kabupaten Demak termasuk dalam penetapan desa yang melaksanakan pengisian perangkat desa; atas Keputusan Bupati Demak tersebut, Pemerintah Desa cabean melaksanakan rapat pembentukan panitia perangkat desa cabean dan menerbitkan Surat Keputusan Kepala Desa tentang pembentukan panitia yang diketuai oleh Sutarman, S.E

Hasil seleksi awal (seleksi administrasi) yang telah dilakukan oleh panitia pengangkatan perangkat desa cabean, menetapan calon perangkat desa yang berhak mengikuti ujian penyaringan Desa cabean Kecamatan Demak kota Kabupaten Demak. pada tahapan selanjutnya, proses seleksi/penyaringan calon perangkat desa mengalami penundaan sampai terbit Peraturan Daerah Kabupaten Demak Nomor 1 tahun 2018 tentang pengangkatan dan pemberhentian Perangkat Desa tertanggal 31 Januari 2018 serta Peraturan Bupati Nomor 7 tahun 2018 tentang petunjuk pelaksanaan Perda Kabupaten Demak Nomor 1 tahun 2018 tertanggal 1 Februari 2018 yang menjadi dasar dan rujukan seleksi pengangkatan perangkat desa di wilayah Kabupaten Demak termasuk dalam hal ini lanjutan proses seleksi pengisian perangkat Desa cabean Kecamatan Demak kota Kabupaten Demak $^{7}$

7 Hasil wawancara dengan Misbakhul Munir, SH.MH Advokat Para Penggugat 


\section{E. PENUTUP}

\section{Simpulan}

a. Proses Pengisian Perangkat Desa Kabupaten Demak yang sempat terhenti pada tahun 2017 pengaturannya berdasarkan Peraturan Daerah Nomor 6 Tahun 2015 tentang Perangkat Desa dan dilanjutkan pada tahun 2018 Berdasarkan Perda No 1 Tahun 2018 Tentang Pengangkatan Dan Pemberhentian Perangkat Desa dilakukan melalui 3 (tiga) tahapan pertama tahap penjaringan yang meliputi pengumuman, pendaftaran dan penetapan calon yang diatur dalam pasal 7 , pasal 8 , pasal 9, pasal 10, pasal 11 pasal 12, pasal 13 dan Pasal 14, Kedua tahap Penyaringan yang meliputi seleksi, Penilaian, dan penetapan hasil seleksi yang diatur dalam pasal 15 , pasal 16 , pasal 17 , pasal 18, dan Pasal 19. Ketiga tahap pengangkatan yang meliputi rekomendasi dan Penetapan melalui SK Kepala Desa yang termuat dalam pasal 21 dan pasal 22. Yang kesemuanya merupakan rangkaian yang utuh dan saling terkait sehingga jika ada salah satu proses yang tidak sesuai maka akan berakibat terjadinya cacat hukum atas produk yang dihasilkan.

b. Adanya gugatan yang dilakukan oleh para penggugat yakni oleh Puspita Budiningtyas yang

Pilperades Cabean pada tanggal 16 November 2018 terregister dalam Pengadilan Tata Usaha Negara Semarang Perkara NO.54/G/2018/PTUN.SMG dikarenakan adanya pelanggaran yang dilakukan Tergugat yakni melanggar pasal 19 dan Pasal 20 Perda No 1 Tahun 2018 Tentang Pengangkatan Dan Pemberhentian Perangkat Desa sebagaimana dalam pertimbangan majlis hakim bahwa telah terjadi pelanggaran Prosedur yakni pasal 19 yang berkaitan dengan pembuatan berita acara hasil seleksi dan pelanggaran subtasi yakni pasal 20 yang berkaitan dengan pihak ketiga, hal ini tidak terlepas dari lemahnya pengawasan yang dilakukan oleh Pemerintah Kabupaten Demak terhadap proses seleksi pengisian perangkat desa sebagaimana tercantum dalam Pasal 37 Perda No 1 Tahun 2018

\section{Saran}

a. Pemerintah Kabupaten Demak dalam menjalankan perda hendaknya dilakukan secara menyeluruh terutama fungsi pengawasan harus dijalankan secara maksimal hal ini untuk memastikan bahwa perda telah dijalankan dengan baik dan meminimalisir sengketa yang mungkin terjadi.

b. Kepala Desa memang mempunyai kewenangan untuk melantik Perangkat Desa, akan tetapi semua tahapan dan proses baik yang bersifat prosedur atau subtansi berdasarkan Perda No 1 
Tahun 2018 harus dilakukan dengan bertanggungjawab.

c. Turut serta masyarakat dalam penyelenggaraan pemerintahan sangat diperlukan hal ini sebagai

\section{DAFTAR PUSTAKA}

\section{Buku-buku}

Titik Triwulan Tutik, Konstruksi Hukum Tata Negara Indonesia PascaAmandemen UUD 1945, Kencana, Jakarta, 2011

Dirjen Peraturan perundang undangan, Panduan Praktis Memahami Perancangan Peraturan Daerah, Penerbit Caplet Project, 2008

H.M. Aziz, Dasar Dasar Konstitusional Pemerintah Daerah Dan Pembentukan Peraturan Daerah.Makalah disampaikan pada pendidikan dan pelatihan penyusunan perancangan peraturan perundang undangan, Jakarta, 2010

\section{Peraturan perundang-undangan}

Undang-Undang Dasar Negara Republik Indonesia 1945

Undang-Undang Dasar RI 1945, Amandemen dan Penjelasannya. Undang-Undang Nomor 23 Tahun 2014 tentang Pemerintah Daerah 